\title{
Perceptions of Student Teachers on Collaborative Relationships Between University and Inclusive Elementary Schools: A Case Study in Indonesia
}

\author{
Rasmitadila, Megan Asri Humaira, \\ Rusi Rusmiati Aliyyah and Reza Rachmadtullah \\ Universitas Djuanda, Indonesia \\ https://orcid.org/0000-0002-0740-1611 \\ https://orcid.org/0000-0002-3969-8966 \\ https:// orcid.org/0000-0002-4908-4677 \\ https://orcid.org/0000-0003-2438-8030
}

\begin{abstract}
This study explores the perceptions of student teachers on the collaborative relationship between inclusive elementary schools (IESs) and universities. Data were collected through online surveys and semistructured interviews with 50 student teachers studying in elementary school teacher education study programs spread across three provinces of Indonesia, namely West Java, Central Java, and East Java. Data were analyzed using thematic analysis. The analysis results found four main themes: inclusive teacher readiness, benefits, inclusive education insights, and inclusive education quality. This study indicates that mutually the collaborative relationship between universities and IESs is very important for the two parties specifically, and for inclusive education in Indonesia generally. Broadly, this research implies that, to establish policies and practices for inclusive education, universities, as the primary authority for producing inclusive teacher candidates, must design programs that are relevant to the problems experienced by IESs. Policymakers, namely the government through the education office, must support and encourage multi-relational collaborative relationships with all parties. To date, the implementation of inclusive education, especially the involvement of all stakeholders in developing inclusive education, follows the policies set by the government - the Ministry of Education, Culture, Research and Technology - of the Republic of Indonesia.
\end{abstract}

Keywords: student teacher; universities; inclusive elementary schools; collaborative relationship; Indonesia

\section{Introduction}

The successful implementation of inclusive education in elementary schools requires the support and cooperation of all stakeholders. Through Government 
Regulation Number 13 of 2020 concerning Adequate Accommodation for Students with Disabilities, the Government of Indonesia, in Article 5 Number 3a, states that universities that offer elementary school teacher education programs for preparing and providing educators and education staff must include the subject of inclusive education. This statement confirms the attachment to and responsibility of higher education institutions (universities) to ensure the competence of student teachers (STs) who will teach in inclusive elementary schools (IESs). Specifically, in Indonesia, graduate teacher candidates who will teach in IESs undergo an elementary school teacher education study program. In this study program, inclusive education subjects are usually taught, with study topics related to the implementation of inclusive education.

Furthermore, to implement the knowledge of theory that STs acquired at university, STs participate in practical work opportunities, do mini research projects, and undertake internships at IESs (Cosner et al., 2015). Implementing this practical work is a form of collaboration between IESs and universities. One of the collaborative relationship goals of IESs is to ensure that STs have quality competencies (i.e., pedagogic, personal, professional, and social competencies) to teach at IESs (DeMatthews, 2020; Nishina et al., 2019; Santos et al., 2016). For this reason, this collaborative relationship between IESs and universities needs to be maintained, continuously and sustainably, so that IESs experience long-term impact and benefits (Ferguson-Patrick, 2020; Buchs et al., 2016). A collaborative relationship involves interaction between two or more people to achieve a common goal, and is based on trust, respect, and shared responsibility (Cook \& Friend, 2010). There are seven essential points involved in developing collaborative relationships: voluntary participation, creating shared goals, sharing resources, shared responsibility for crucial decisions, shared accountability for results, equal parity or contribution of all participants, and the trust and respect that arises (Friend et al., 1993).

The benefits of collaborative relationships with IESs include, for universities, the opportunity to develop programs (Rodriguez, 2019; Jeffries, 2019), that are relevant to the problems faced by IESs. The university gains input from IESs for course development programs for highly inclusive education, and for preparing STs to acquire quality competencies; the university's STs also have the opportunity to practice inclusive education courses at IESs. For STs, the benefits of collaborative relationships between universities and IESs relate to the new skills in instruction they can gain by learning to provide intervention to students with special needs in instruction (Cahill \& Mitra, 2008), and professional development and curriculum reform components (White et al., 1997). Meanwhile, for IESs that have this collaborative relationship with universities, research could solve problems that occur in inclusive classrooms (Santos et al., 2016; Derzhavina et al., 2021; Zelina, 2020). Therefore, IESs must open themselves to a variety of parties, including universities, to get access to quality programs and to help solve problems related to inclusive classrooms. Among the problems that are often faced by IESs are teachers' lack of understanding of student characteristics, difficulties related to identifying students who are special students, instructional design, and student assessment. 
However, in practice, there are still IESs that do not have collaborative relationships with external parties, including universities, thus, affecting inclusive practices at schools. A previous study by the authors of this paper (Rasmitadila et al., 2021) reports that it is difficult to encourage schools that are not yet collaborating with other parties (universities, NGOs, psychologists) to support the implementation of inclusive education, which results in schools feeling that they alone bear all the obligations in relation to inclusive education. The condition of IESs in Indonesia - an archipelagic country - causes various situations and problems that impact on inclusive education providers, especially in areas far from urban areas. Some areas are located far from universities offering elementary school teacher education study programs, and the lack of access to universities prevents IESs from establishing collaborative relationships with universities. In turn, not all universities have elementary school education study programs that can accommodate the needs of IESs.

As a result, the various problems faced by IESs have to be solved by the schools themselves, and they cannot rely on interventions by other parties, such as universities. So far, the collaborative relationship between universities and IESs is a one-way relationship that mainly benefits the university. For example, the internship programs organized by universities for STs at elementary schools (general schools and inclusive schools) is only intended to fulfil STs' course requirements. Other programs, such as research conducted by STs at IESs, only benefit STs, as it is a graduation requirement, and the research does not provide solutions for the problems faced by IESs. In other words, IESs are merely sites that help to fulfil university needs by providing opportunities to fulfil STs' study requirements. Therefore, this relationship does not describe a collaborative relationship that benefits both universities and IESs.

If universities enter into collaborative relationships with IESs, both parties can provide input, through which inclusive education can be improved (Nishina et al., 2019; Futaba, 2016; Page et al., 2021). Universities need information from IESs on events on the ground. In inclusive administration, universities must solve problems through research or by improving course content to meet IESs' needs. Likewise, IESs could obtain input and solutions to problems related to implementing inclusive education, such as curriculum, learning, student behavior, and the procurement of infrastructure (Billingsley et al., 2018; Asiri, 2020; Aktan, 2020).

The most relevant implementation in teacher education study programs is the provision of inclusive education courses for STs. Input by IESs is essential for the development of inclusive education courses. Instruction must contain current topics, and be based on real experiences of teachers in inclusive schools and research results that can provide solutions to inclusive problems facing inclusive education. Compulsory subjects that STs must take must cover topics such as characteristics of students with special needs (SSNs), identifying SSNs, instructional design in inclusive classrooms and for individual learning programs, and instructional assessment. STs must be able to apply the theory they learn in 
practice directly at IESs, so that STs gain experience of the real picture regarding inclusive implementation. In the end, STs understand when they complete their studies that inclusive practice requires an excellent collaborative relationship between universities and IESs, and that they should apply theory to achieve accurate and relevant practice. Universities must design programs jointly with IESs, to establish mutually beneficial collaborative relationships in the future.

This study explored the opinions of STs about the collaborative relationship between universities and IESs that exists in Indonesia.

\section{Methodology}

\subsection{Research Design}

This study used a case study, which is a type of qualitative research. The purpose of a case study is to provide an opportunity for researchers to obtain and examine data in relation to a particular context or phenomenon. Cases can be selected, especially in education, and could involve parents, students, school staff, educators and members of the school community (Crowe et al., 2011; Yin, 2012). In a case study, the data is used to provide an in-depth and comprehensive overview of cases found in real life (Yin, 2012). Specifically, in this study, the perceptions of STs on the relationship between universities and IESs in Indonesia were explored in depth.

Literature was referenced to determine the conceptual and operational description of the research focus, namely data relating to the relationship between universities and IESs. The instruments used for data collection were based on conceptual and operational descriptions that focused on the relationship, benefits, and forms of university-IES relationships. Data collection was carried out in stages through an online survey and semi-structured interviews that were conducted to obtain in-depth data. Data analysis applied established procedures according to predetermined indicators (Clarke et al., 2015).

\subsection{Participants}

The participants in this study were 50 STs at universities that run teaching faculties with elementary school teacher education study programs in three provinces in Indonesia, namely West Java, Central Java, and East Java. These three provinces were selected because they had the largest number of elementary schools, and universities offering elementary school teacher education study programs. STs were involved in this study because an ST undergoes a lecture process - theory and practice - in instruction, especially in inclusive education courses, to gain relevant competencies for teaching at IESs after graduating from university. Therefore, STs must be prepared appropriately to solve the main problems in inclusive classrooms. This condition illustrates that STs are teacher candidates who will teach at IESs. The STs involved in this study met two criteria: first, students had completed at least semester 6 (three years of study), had passed inclusive education courses and had practical experience in the field, or had done internships. Second, students had recently graduated and already have teaching experience at IESs. 
A purposive sampling technique was used and online questionnaires were distributed, using Google Forms, to representatives of research colleagues who had access to universities in the three provinces. Descriptive data on participants' demographic characteristics, including gender, teaching experience, and semester, are presented in Table 1.

Table 1: Profile of participants

\begin{tabular}{|l|c|c|}
\hline Gender & Frequency & $\%$ \\
\hline Male & 3 & 6 \\
\hline Demale & 47 & 94 \\
\hline Three years & 14 & 28 \\
More than three years & 36 & 72 \\
\hline Experience of teaching practice & 24 & 48 \\
\hline Internship at IESs & 26 & 52 \\
Teaching at IESs & 2 & \\
\hline
\end{tabular}

\subsection{Data Collection Instruments}

Data collection took place in two stages. The first stage collected data from STs who met the two criteria described in the participant section. Data was collected using an online survey with six main questions, in essay format and using Google Forms (See Appendix 1). The questions were compiled after the literature relevant to the research objectives had been studied. Data were collected from July 2, 2021July 9, 2021, and involved 50 participants. A transcript was made of the responses of each participant, and preliminary codes were identified. Participants who met the first criterion had mostly positive opinions. Their positive opinions were possibly because, at that stage, they had not had teaching experience at IESs, so the problems faced by inclusive schools were not yet fully understood by STs. Meanwhile, participants who met the second criterion tended to respond negatively. These STs already had personal experience of teaching inclusive classes, and had first-hand experience of problems.

The second data collection stage involved semistructured interviews with four of the 50 STs who had completed the survey. Four STs were selected for interviews to obtain more in-depth data than that provided in the online survey. The answers the four STs provided were clear and easily understood by the researchers. The researchers had prepared an interview guide based on the initial codes derived from the first stage (see Appendix 2). Interviews lasted about an hour each, and were done through the WhatsApp (Video Call) application between July 11, 2021 and July 14, 2021. 


\subsection{Data Analysis}

The data was analysed through a thematic analysis technique, in order to identify, evaluate and reveal the main themes (Braun \& Clarke, 2012; Galloway \& Jenkins, 2009). In the first stage, responses by or opinions of STs were allocated certain codes in the form of keywords that match the interpretation of sentences or specific terms; care was taken to prevent overlap. Next, researchers used NVivo 12 to facilitate coding and organize specific categories. The codes formed a thematic map that showed the organization of concepts, ready for further development. The code that was generated started with systematic categorization of quotations in the data obtained from each ST to find themes and patterns. In the initial step, the researchers read the data of all participants (STs) and created and applied codes to certain responses, over several coding rounds. Next, the researchers analyzed all the codes and categorizations to determine what could be merged, or split, between the codes. Finally, the remaining codes became more specific, and could be used to answer the research questions.

The credibility and dependability of research received serious consideration. The process started with the data collection instrument being based on the literature review. Furthermore, inclusive education experts were involved. After the data had been collected, member checking (Lincoln et al., 1985) was done, to check the accuracy of the recordings of the data provided by the participants (especially for the data obtained from the interviews); STs were asked to confirm that their contributions were accurately reflected in the data. Meanwhile, researcher triangulation was also conducted to reduce bias, by cross-examining participants (Shenton, 2004). Involving all the researchers in an examination of the data with the research problem in mind enhanced the integrity of the findings.

\section{Results}

This study examined the opinions of STs about the collaborative relationship between universities and IESs in three provinces in Indonesia. The findings of this study indicate that the STs' perceptions of the inclusive university-IES relationship is essential for the development of inclusive education in Indonesia. Four main themes emerged from the findings, illustrating that inclusive university-elementary school relationships can be a way to develop better inclusive education, including inclusive teacher readiness, to ensure benefits, to obtain insights on inclusive education, and ensure inclusive education quality. See Figure 1. 


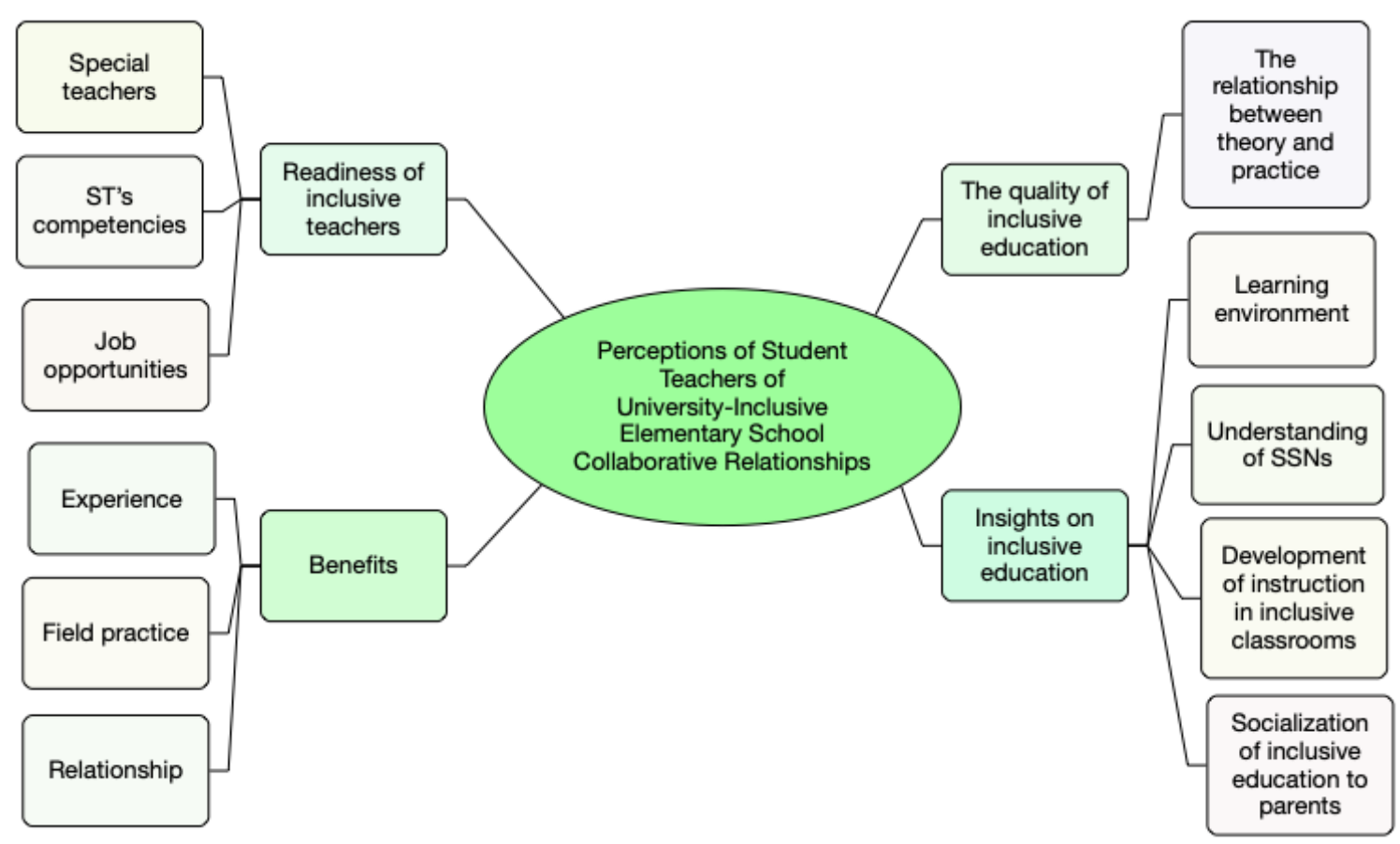

Figure 1: Result analysis of the perceptions of student teachers of university-IES relationships (use NVivo 12)

\subsection{Readiness of inclusive teachers}

The findings show that the readiness of inclusive teachers for teaching is one of the main determinants of success of inclusive education provided by IESs. This theme produced three subthemes: aided teachers, STs' competencies, and job opportunities.

Regarding the subtheme of aided teachers, STs argued that the role of aided teachers is one aspect of supporting successful instruction in inclusive classrooms. Unfortunately, many IESs do not have aided teachers who can assist general teachers in dealing with SSNs. The task of general teachers becomes challenging when they have to accommodate the needs of all the students in the class. Universities are expected to provide study programs that promote the competence of aided teachers. This opinion was expressed by an ST:

Because I also think that an elementary school teacher can be used as a companion teacher in an IES later. Therefore, I believe it is important to have such a collaborative relationship, such as a department on aided teachers at universities (ST 8).

The second subtheme finding relates to the competence of STs, which must be developed by universities so that graduates can perform their duties as inclusive teachers at IESs. Therefore, STs argued that teacher competence must be adapted to the needs of IESs. Universities must provide inclusive education lecture material on topics related to the problems faced by IESs, which are interconnected. STs believed that the relationship between universities and IESs must be maintained, especially regarding programs for inclusive education courses and the development of STs' competencies, so that, when STs graduate, they have high competence. This opinion was explained by STs: 
I think universities should continue to collaborate with IESs so that their graduates, when they become inclusive teachers, can perform their duties well (ST 4).

With cooperation universities can develop programs and what needs to be prepared for students who will become inclusive teachers of inclusive schools so that what they learn can be applied properly later (ST 21).

In addition to the findings on other subthemes related to job opportunities, STs believed that the relationship between universities and IESs has opened up job opportunities for STs who will teach at inclusive schools. Universities can develop and reach agreements with IESs about graduates working and teaching at the schools. An ST explained their opinion:

The collaborative relationship between universities and IESs can be done by including STs or graduates who will teach at the IES (ST 10).

The ST states that preparing and developing inclusive teachers at universities is an important way to assist IESs. For this reason, a mutually collaborative relationship between the two entities must be established, because these STs and graduates will teach at IESs in the near future. In addition, STs implement course material in inclusive classrooms to solve problems that arise in their classrooms (Liasidou, 2015; Graham et al., 2015; Scott, 2017).

\subsection{Benefits}

The findings on the theme of benefits perceived by STs consist of three subthemes: experience, field practice, and relationships. According to STs, relationships of cooperation between IESs will provide STs with experience when they teach at IESs. If universities have collaborative relationships with IESs, and if they offer programs, such as internships or field practice, it becomes easier for STs, as candidate teachers, to recognize the SSNs are often found in inclusive classrooms. STs will see and experience first-hand the learning that takes place in inclusive classrooms, and will learn how to deal with SSNs, thereby providing new experiences for STs. This opinion was explained by the STs:

In my opinion, if the university has a collaborative relationship, it will cause students to have new experiences about inclusive schools (ST 11).

It is important because it can improve the ST's experience in dealing with students (ST 4).

According to STs, the second subtheme finding is related to the benefits of the relationship between universities and IESs. STs can practice directly at IESs, by participating in programs designed by universities and implemented at IESs. A collaborative relationship will enable universities to carry out these programs. Through field practice, ST candidates can apply theory or knowledge gained during lectures to practice. For example, in inclusive classroom instruction, STs will receive input from inclusive teachers who are experienced in teaching in inclusive classrooms regarding both academic and non-academic aspects; this will 
provide new knowledge to STs and confirm the theory they have been taught. An ST explained this opinion:

It is necessary to have an internship at the school so that they can learn directly to see their instruction, get input and teaching experience (ST 38).

Another subtheme finding is that the collaborative relationship between IESs and universities is a relationship that could benefit both parties. The better the relationship the university establishes, the more programs can be implemented to provide opportunities for STs to develop themselves into 'ready-to-use' graduates. An ST explained this opinion:

The more collaborative relationships that exist, the better it is for all relations. So, for example, for universities, the more relations, the more programs that can be offered, which can be implemented especially in IESs, which is very beneficial for student teachers (ST 40).

According to STs, the benefits of the collaborative relationship between universities and IESs will provide opportunities and benefits for both parties. Universities can create relevant programs and provide support. so that the STs achieve success as prospective inclusive teachers in IESs while they gain new experiences (Sharma, 2018; Steinbeck, 2016; Dewsbury \& Brame, 2019). For IESs, the input given by class teachers to STs during internships will improve the contents of lectures at universities (Sindelar et al., 2014; Hornby, 2014).

\subsection{Insights on Inclusive Education}

Findings on the theme of insights on inclusive education resulted in several subthemes: learning environment, understanding of SSNs, development of instructions in inclusive classrooms, and socializing parents about inclusive education.

Opinions of STs regarding the learning environment are related to the implementation of the content of the course in the learning environment in inclusive classrooms when STs later teach in inclusive classrooms during field practice at IESs. STs argue that they must understand the inclusive classroom learning environment, which they can only do if the practice in the classroom is inclusive. For this reason, a collaborative relationship between universities and IESs will enable STs to experience, first-hand, the instructional activities that must be created to obtain conducive learning environments in IESs. This opinion was explained by an ST:

If there is a collaboration with IESs when STs practice directly at IESs, STs will be able to see the student learning environment directly. This will add to the experience for STs (ST 42).

The other subtheme relating to insight into inclusive education is understanding SSNs. STs state that a collaborative relationship between universities and IESs will enable STs to determine the various characteristics of SSNs in inclusive classrooms. Through visits to IESs, or through internships, STs could gain handson experience of handling SSNs. It is hoped that this experience will be implemented when STs become inclusive teachers after graduating from 
university. STs are expected to discover the links between theories they have learned about in inclusive education courses, and to learn about the various characteristics of SSNs in inclusive classrooms. The opinions of STs were as follows:

I think the collaborative relationship between teaching faculties and IESs is significant, and with this relationship, it can increase our knowledge about how to teach inclusive children (ST 24).

With this collaborative relationship, it will help and train an ST, especially as a prospective elementary school teacher in knowing or deepening student characteristics" (ST 23).

Another finding reflected in STs' opinions is related to understanding the development of instruction in inclusive classrooms. The opinion of STs about the existence of collaborative relationships between universities and IESs can broaden STs' insight into the characteristics of SSN, including about the development of instruction in inclusive classrooms. This understanding occurs when students practice directly in inclusive classrooms in IESs. According to STs, the opportunity given to STs by an internship program can help STs to improve their teaching in inclusive schools. STs can interact with all students in inclusive classrooms, be aware of the latest learning developments and present it in a fun way, and apply learning theory they learned about at university. STs gave the following opinions:

With the collaboration that is established between the university/faculty (teachers) and IESs, it can help STs to determine how they can teach in inclusive schools properly and correctly (ST 5).

To know the development of instruction in IESs today (ST 11).

STs expressed opinions about raising the awareness of parents about inclusive education, which could provide opportunities for universities, as higher education institutions that have the authority to educate the community and parents that inclusive education is a form of education that supports diversity. In addition, universities can help IESs. In addition, universities can assist IES in developing inclusive education, including outreach to parents and communities that do not understand inclusive education. For example, this opinion was expressed by an ST:

With the help of universities, you can get elementary schools to include familiarization of inclusive education to parents who have children with special needs so that they want to send their children to IESs (ST 14).

\subsection{The Quality of Inclusive Education}

The finding on this theme is that quality of education is one of the goals of inclusive education. STs argued that a collaborative relationship between universities and IESs can affect the quality of inclusive education. With this collaboration, STs can apply the knowledge gained in lectures at university at IESs, and practice appropriate instruction for inclusive classrooms. Programs that are mutually agreed upon between universities and IESs can improve the quality of inclusive education, especially at IESs. A ST explained this opinion: 
Because the collaboration between universities and IESs can improve the quality of education in Indonesia, especially inclusive education that combines regular students and students with special needs (ST 25).

Another opinion expressed by an ST about improving the quality of inclusive education is that, when there is a collaborative relationship between IESs and universities, STs learn the theory at university and practice it at IESs. This means that this relationship will allow STs to relate the theory they learned with actual activities at IESs. Therefore, the impact of the relationship will be felt in the long term, by improving the quality of inclusive education in Indonesia. This opinion was explained by STs:

STs can practice theory in the real field to determine the development of inclusive education (ST 23).

Not only with theory, but you can practice directly at the school so that it can show the success of the education (ST 37).

Findings related to this theme indicate that IESs can improve the quality of inclusive education by developing collaborative relationships with universities. The quality of education can be improved by STs applying the theory learned in lectures at universities during direct practice at IESs (Watkins \& Meijer, 2016; Choi \& Park, 2018)

\section{Discussion}

The success of inclusive education in Indonesia is the responsibility of all parties, including universities. Moreover, the current policy in Indonesia is that all elementary schools must accept SSNs. Building collaborative relationships between universities and IESs is one way of achieving success. The collaborative relationship between IESs and universities is a significant reciprocal relationship for implementing inclusive education in Indonesia. This reciprocal relationship aims to solve problems that arise in the implementation of inclusive education in IESs (Clark, 1999; Ruairc, 2013; Kinsella, 2020). Universities should investigate all problems, especially those that relate to elementary school teacher education programs, and must design course content that addresses these problems.

Various problems that have, thus far, become central factors in implementing inclusive education in IESs in Indonesia include shortcomings in the competence of inclusive teachers - classroom teachers - who come from different backgrounds to teach in inclusive classrooms. As a result, teachers are not always able to teach inclusive classes, and are unable to meet the needs of all students with different characteristics. In contrast, an essential element of inclusive education is ensuring that all teachers are ready to teach all students, or can act as agents of change to change the view that some students are less or unable to learn (Eres, 2016; Regalla \& Peker, 2017; Schwab et al., 2021). As producers of elementary school teachers, universities must design courses or programs that can produce graduates who can become inclusive teachers at IESs. The content of courses and programs that can produce competent graduates must be based on the problems that have emerged thus far at IESs. 
The collaborative relationships between universities and IESs are expected to provide benefits for both parties. For universities, real programs, such as field practice or internships for STs, will offer STs new opportunities to implement the theory learned during lectures (Hope, 2015; Davidsen \& Tam, 2010). Experience gained from practical work done at IESs will help STs understand and become familiar with adapting to the work environment they will face when they graduate. In addition, through practical work and internship programs, STs will gain both broad and deep insights related to comprehensive inclusive education. For example, STs will learn to understand the characteristics of SSNs, which they had only learned about in lectures (Lindqvist \& Nilholm, 2014; Grimes, 2013; Ainscow, 2018). Practical work in inclusive classrooms will teach STs to deal with S directly and to find solutions to problems faced by SSNs. STs will also be able to collaborate with general teachers to design effective instructional systems for inclusive classrooms, and thereby to achieve learning objectives according to the goals that have been set (Kapalka, 2005; Hagiwara \& Shogren, 2018). Achieving learning objectives depends on an inclusive classroom learning environment that is conducive and comfortable for all students. For this reason, STs must learn from general teachers to create a friendly and fun learning environment for all class members. All practical work activities in inclusive classrooms can serve as input for all parties, especially for universities, IESs, and educators in this collaborative relationship (Jardí et al., 2021; Bubpha, 2014; Toson et al., 2013).

The input given by classroom teachers in IESs will guide STs to improve and develop themselves, so that they are ready, upon graduation, to teach in inclusive classrooms. For universities, collaborative relationships with IESs through fieldwork programs can help to improve programs and course content for inclusive education, so that it is more relevant and in line with the rapid changes that are taking place in inclusive practice (Okabe \& Tsuge, 2019; Kremsner, 2021; Done et al., 2013). In addition, universities, which have authority in the field of research, can disseminate research results to IESs to solve the problems that often arise. All research findings and evaluations of practical work or internship programs should form the basis for making changes to the development of inclusive education (Ahmad, 2018; Miles \& Singal, 2010; Mulyadi, 2017), so that the quality of inclusive education in Indonesia improves.

\section{Conclusion}

This study explored STs' perceptions of the collaborative relationship between universities and IESs. This collaborative relationship is significant and mutually beneficial for both parties, and promotes inclusive education in Indonesia. However, considering the problems being experienced by IESs, the collaborative relationship between universities and IESs needs to be systematically and comprehensively designed through an actual program that approaches it systematically and comprehensively, which refers to the readiness of inclusive human capital and an inclusive instructional system that is needed to achieve inclusive education goals. The research results presented in this paper have implications for establishing inclusive education policies and practices for universities - as the major authority that produces graduates who move on to 
serve as inclusive teacher candidates at IESs. In addition, policymakers, namely the government through the education office, must support and encourage the establishment of multi-relational collaborative relationships between all parties, so that the implementation of inclusive education adheres to the policies that have been set so far.

\section{Acknowledgments}

The authors wish to thank the Ministry of Education and Culture, Research and Technology, which funded research as part of Penelitian Terapan Unggulan Perguruan Tinggi (PTUPT) (2021). Special thanks goes to the Directorate of Research and Service of Universitas Djuanda, which supported the research.

\section{References}

Ahmad, N. A. (2018). Inclusive education: Better and for the best. International Journal of Academic Research in Progressive Education and Development, 7(3), 557-568. https://doi.org/10.6007/IJARPED/v7-i3/4574

Ainscow, M. (2018). Special needs through school improvement; school improvement through special needs. In C. Clark, A. Dyson, \& A. Millward (Eds.), Towards inclusive schools? (pp. 63-77). Routledge. https://doi.org/10.4324/9780429469084-6

Aktan, O. (2020). Determination of educational needs of teachers regarding the education of inclusive students with learning disability. International Journal of Contemporary Educational Research, 7(1), 149-164. https://doi.org/10.33200/ijcer.638362

Asiri, A. A. (2020). Teachers' perceptions of educational administers' support for inclusive education. Journal of Education and Learning, 9(6), 112. https://doi.org/10.5539/jel.v9n6p112

Billingsley, B., DeMatthews, D., Connally, K., \& McLeskey, J. (2018). Leadership for effective inclusive schools: Considerations for preparation and reform. Australasian Journal of Special and Inclusive Education, 42(1), 65-81.

Braun, V., \& Clarke, V. (2012). Thematic analysis. In H. Cooper, P. M. Camic, D. L. Long, A. T. Panter, D. Rindskopf, \& K. J. Sher (Eds.), APA handbook of research methods in psychology, Vol 2: Research designs: Quantitative, qualitative, neuropsychological, and biological (pp. 57-71). American Psychological Association. https://doi.org/10.1037/13620-004

Bubpha, S. (2014). Models of inclusive education: One size does not fit all. International Journal of Technology and Inclusive Education, 3(2), 328-334. https://doi.org/10.20533/ijtie.2047.0533.2014.0042

Buchs, C., Gilles, I., Antonietti, J-P., \& Butera, F. (2016). Why students need to be prepared to cooperate: A cooperative nudge in statistics learning at university. Educational Psychology, 36(5), 956-974.

Cahill, S. M., \& Mitra, S. (2008). Forging collaborative relationships to meet the demands of inclusion. Kappa Delta Pi Record, 44(4), 149-151. https://doi.org/10.1080/00228958.2008.10516513

Choi, H.-I., \& Park, S. H. (2018). Teachers' evaluation of inclusive education practices in elementary schools at Seoul: Using the quality indicators of elementary inclusive education. Korean Journal of Special Education, 53(2), 23-52. https:// doi.org/10.15861/kjse.2018.53.2.23

Clark, C. (1999). Inclusive education and schools as organizations. International Journal of Inclusive Education, 3(1), 37-51. https://doi.org/10.1080/136031199285174

Clarke, V., Braun, V., \& Hayfield, N. (2015). Thematic analysis. In J. A. Smith (Ed.), Qualitative psychology: A practical guide to research methods (pp. 222-248). Sage.

Cook, L., \& Friend, M. (2010). The state of the art of collaboration on behalf of students with disabilities. Journal of Educational and Psychological Consultation, 20(1), 1-8. 
Cosner, S., Kimball, S. M., Barkowski, E., Carl, B., \& Jones, C. (2015). Principal roles, work demands, and supports needed to implement new teacher evaluation. Mid-Western Educational Researcher, 27(1), 76-95.

Crowe, S., Cresswell, K., Robertson, A., Huby, G., Avery, A., \& Sheikh, A. (2011). The case study approach. BMC Medical Research Methodology, 11(1), 1-9. https://doi.org/10.1186/1471-2288-11-100

Davidsen, C., \& Tam, C.-L. (2010). Power and knowledge constraints of multidisciplinary learning: Field school experiences in practice. The Journal of the World Universities Forum, 3(4), 119-126. https:// doi.org/10.18848/1835-2030/CGP/v03i04/56697

DeMatthews, D. (2020). Undoing systems of exclusion: Exploring inclusive leadership and systems thinking in two IESs. Journal of Educational Administration, 59(1), 5-21.

Derzhavina, V. V., Nikitina, A. A., Makarov, A. L., Piralova, O. F., Korzhanova, A. A., Gruver, N. V., \& Mashkin, N. A. (2021). Inclusive education importance and problems for students social integration. Propósitos y Representaciones, 9(SPE3), 1130.

Dewsbury, B., \& Brame, C. J. (2019). Inclusive teaching. CBE - Life Sciences Education, 18(2), fe2.

Done, E., Murphy, M., \& Irving, M. (2013). In search of inclusive non-dualistic pedagogies through collaborative and affective learning events. International Journal of Inclusive Education, 17(6), 584-596. https:/ / doi.org/10.1080/13603116.2012.694913

Eres, F. (2016). Problems of the immigrant students' teachers: Are they ready to teach? International Education Studies, 9(7), 64. https://doi.org/10.5539/ies.v9n7p64

Ferguson-Patrick, K. (2020). Cooperative learning in Swedish classrooms: Engagement and relationships as a focus for culturally diverse students. Education Sciences, 10(11), 312. https:// doi.org/10.3390/educsci10110312

Florian, L., \& Beaton, M. (2018). Inclusive pedagogy in action: Getting it right for every child. International Journal of Inclusive Education, 22(8), 870-884.

Friend, M., M. Reising, and L. Cook. 1993. Co-teaching: An overview of the past, a glimpse at the present, and considerations for the future. Preventing School Failure, 37(4), 610.

Futaba, Y. (2016). Inclusive education under collectivistic culture. Journal of Research in Special Educational Needs, 16(S1), 649-652. https:/ / doi.org/10.1111/1471-3802.12325

Galloway, F. J., \& Jenkins, J. R. (2009). The adjustment problems faced by international students in the United States: A comparison of international students and administrative perceptions at two private, religiously affiliated universities. NASPA Journal, 46(4), 661-673.

Graham, L., Berman, J., \& Bellert, A. (2015). Sustainable learning: Inclusive practices for 21st century classrooms. Cambridge University Press. https://doi.org/10.1017/CBO9781107280243

Grimes, P. (2013). Considering the continuing development of inclusive teachers: A case study from Bangkok, Thailand. European Journal of Special Needs Education, 28(2), 187-202. https:// doi.org/10.1080/08856257.2013.778112

Hagiwara, M., \& Shogren, K. A. (2018). Collaborate with families to support student learning and secure needed services. In J. McLeskey, L. Maheady, B. Billingsley, M. T. Brownell, \& T. J. Lewis (Eds.), High leverage practices for inclusive classrooms (pp. 34-47). Routledge. https://doi.org/10.4324/9781315176093-4

Hope, J. (2015). Implement experiences transcripts to provide a more complete student record. The Successful Registrar, 15(6), 1-5. https:// doi.org/10.1002/tsr.30085

Hornby, G. (2014). Inclusive special education. Evidence-based practices for children with special needs and disabilities. Springer. https://doi.org/10.1007/978-1-4939-1483-8_5

Jardí, A., Puigdellívol, I., \& Petreñas, C. (2021). Teacher assistants' roles in Catalan classrooms: Promoting fair and inclusion-oriented support for all. International Journal of Inclusive Education, 25(3), 313-328. https://doi.org/10.1080/13603116.2018.1545876 
Jeffries, R. (Ed.). (2019). Diversity, equity, and inclusivity in contemporary higher education. IGI Global. https://doi.org/10.4018/978-1-5225-5724-1

Kapalka, G. M. (2005). Successful teaching in inclusive classrooms: How can we help teachers utilize the most effective strategies? PsycCRITIQUES, 50(28). https://doi.org/10.1037/05173111

Kinsella, W. (2020). Organising inclusive schools. International Journal of Inclusive Education, 24(12), 1340-1356. https://doi.org/10.1080/13603116.2018.1516820

Kremsner, G. (2021). Becoming an inclusive teacher: Reducing gaps in theory and practice through inclusive research. International Journal of Inclusive Education, https:// doi.org/10.1080/13603116.2021.1882055

Liasidou, A. (2015). Inclusive education and the issue of change - policy and practice in the classroom. Palgrave Macmillan. https://doi.org/10.1057/9781137333704.0007

Lincoln, Y. S., Guba, E. G., \& Pilotta, J. J. (1985). Naturalistic inquiry. International Journal of Intercultural Relations, 9(4), 438-439. https://doi.org/10.1016/01471767(85)90062-8

Lindqvist, G., \& Nilholm, C. (2014). Promoting inclusion? 'Inclusive' and effective head teachers' descriptions of their work. European Journal of Special Needs Education, 29(1), 74-90. https://doi.org/10.1080/08856257.2013.849845

Miles, S., \& Singal, N. (2010). The Education for All and inclusive education debate: Conflict, contradiction or opportunity? International Journal of Inclusive Education, 14(1), 1-15. https://doi.org/10.1080/13603110802265125

Mulyadi, A. W. E. (2017). Policy of Inclusive Education for Education for All in Indonesia. Policy \& Governance Review, 1(3), 201. https://doi.org/10.30589/pgr.v1i3.57

Nishina, A., Lewis, J. A., Bellmore, A., \& Witkow, M. R. (2019). Ethnic diversity and inclusive school environments. Educational Psychologist, 54(4), 306-321.

Okabe, H., \& Tsuge, M. (2019). Snapshot-Importance of classroom atmosphere in elementary schools to improve the inclusive education system in Japan. In S. L. Gronseth \& E. M. Dalton (Eds.), Universal access through inclusive instructional design (pp. 269-271). Routledge. https:// doi.org/10.4324/9780429435515-36

Page, A., Charteris, J., Anderson, J., \& Boyle, C. (2021). Fostering school connectedness online for students with diverse learning needs: Inclusive education in Australia during the COVID-19 pandemic. European Journal of Special Needs Education, 36(1), 142-156.

Rasmitadila., Humaira, M. A., \& Rachmadtullah, R. (2021). Teachers' perceptions of the role of universities in mentoring programs for IESs: A case study in Indonesia. Journal of Education and E-Learning Research, 8(3), 333-339. https://doi.org/10.20448/journal.509.2021.83.333.339

Regalla, M., \& Peker, H. (2017). Prompting all students to learn: Examining dynamic assessment of special needs and typical students in a prekindergarten inclusive French program. Foreign Language Annals, 50(2), 323-338. https://doi.org/10.1111/flan.12261

Rodriguez, J. (2019). Exploring the challenges and benefits to inclusive education in Jordanian UNRWA schools. Multiple Voices for Ethnically Diverse Exceptional Learners, 19(1), 44-57.

Ruairc, G. M. (2013). Leading inclusive schools. In G. M. Ruairc, E. Ottesen, \& R. Precey, Leadership for inclusive education (pp. 71-80). SensePublishers. https://doi.org/10.1007/978-94-6209-134-4_7

Santos, G. D., Sardinha, S., \& Reis, S. (2016). Relationships in inclusive classrooms. Journal of Research in Special Educational Needs, 16(S1), 950-954. ttps://doi.org/10.1111/1471-3802.12238

Schwab, S., Resch, K., \& Alnahdi, G. (2021). Inclusion does not solely apply to students with disabilities: Pre-service teachers' attitudes towards inclusive schooling of all 
students. International Journal of Inclusive Education, 1-17. https://doi.org/10.1080/13603116.2021.1938712

Scott, T. M. (2017). Teaching behavior: Managing classrooms through effective instruction. Corwin. https:/ / doi.org/10.4135/9781506337883

Sharma, U. (2018). Preparing to teach in inclusive classrooms. In Oxford research encyclopedia of education. Oxford University Press. https://doi.org/ 10.1093/acrefore/9780190264093.013.113

Shenton, A. K. (2004). Strategies for ensuring trustworthiness in qualitative research projects. Education for Information, 22(2), 63-75. https://doi.org/10.3233/EFI-200422201

Sindelar, P. T., Adams, A. J., \& Leko, C. D. (2014). How can teacher education improve effective inclusive schools? In J. McLeskey, N. L. Waldron, F. Spooner, \& B. Algozzine (Eds.), Handbook of effective inclusive schools. Routledge. https://doi.org/10.4324/9780203102930.ch5

Steinbeck, K. (2016). Inclusive schools - Inclusive teachers? How much special needs preparation does a pre-service teacher need to teach successfully in an inclusive school system? In I. Harrington, N. Kastirke, \& L. Holtbrink (Eds.), Inklusion in Deutschland und Australien (pp. 125-139). Springer Fachmedien Wiesbaden. https://doi.org/10.1007/978-3-658-14463-0_7

Thomas, G. (1997). Inclusive schools for an inclusive society. British Journal of Special Education, 24(3), 103-107. https://doi.org/10.1111/1467-8527.00024

Toson, A. L.-M., Burrello, L. C., \& Knollman, G. (2013). Educational justice for all: The capability approach and inclusive education leadership. International Journal of Inclusive Education, 17(5), 490-506. https:/ / doi.org/10.1080/13603116.2012.687015

Watkins, A., \& Meijer, C. (Eds.). (2016). Implementing inclusive education: Issues in bridging the policy-practice gap. In C. Forlin (Ed.), International perspectives on inclusive education (Vol. 8, p. iii). Emerald Group Publishing. https://doi.org/10.1108/S1479-363620160000008023

White, C. S., Deegan, J. G., \& Allexsaht-Snider, M. (1997). Changes in roles and relationships in a school-university partnership. Teacher Education Quarterly, 24(1), 53-66.

Yin, R. K. (2012). Case study methods. In H. Cooper, P. M. Camic, D. L. Long, A. T. Panter, D. Rindskopf, \& K. J. Sher (Eds.), APA handbook of research methods in psychology, Vol. 2. Research designs: Quantitative, qualitative, neuropsychological, and biological (pp. 141-155). American Psychological Association. https:// doi.org/10.1037/13620-009

Zelina, M. (2020). Interviews with teachers about inclusive education. Acta Educationis Generalis, 10(2), 95-111. 


\section{Appendix 1}

The questions of online survey

\begin{tabular}{|l|l|}
\hline A. Profile of the participants & Answer \\
\hline Name of participant (initial) & \\
\hline Gender & \\
\hline Length of studies (years) & \\
\hline Experience of teaching practice & $\begin{array}{l}\text { between the University/Faculty (Teaching) and IESs? Give your } \\
\text { reason }\end{array}$ \\
\hline $\begin{array}{l}\text { B. What do you think the form of a cooperative relationship is? } \\
\text { Give an example }\end{array}$ & \\
\hline $\begin{array}{l}\text { 3. Do you think the university will benefit from the cooperative } \\
\text { relationship with the IES? Give the reason }\end{array}$ & \\
\hline $\begin{array}{l}\text { 4. Do you think the benefits of IESsare related to the cooperative } \\
\text { relationship with the university? Give the reason }\end{array}$ & \\
\hline $\begin{array}{l}\text { 5. In your opinion, is there a need for assistance provided by } \\
\text { universities to IESs? Give your reason }\end{array}$ & \\
\hline $\begin{array}{l}\text { 6. In your opinion, so far, the University has provided direct and } \\
\text { ongoing assistance to IESs? Give the reason }\end{array}$ & \\
\hline
\end{tabular}

\section{Appendix 2}

\section{Interview guideline}

\begin{tabular}{|l|l|}
\hline Question & Answer \\
\hline $\begin{array}{l}\text { 1. What is the long-term impact for inclusive primary schools from } \\
\text { this cooperative relationship? }\end{array}$ & $\begin{array}{l}\text { 2. What is the most important material to give to students } \\
\text { regarding inclusive education? }\end{array}$ \\
\hline $\begin{array}{l}\text { 3. What are the most relevant forms of activity so that IESs get } \\
\text { solutions to problems that have often occurred? }\end{array}$ & \\
\hline
\end{tabular}

